\title{
Heifer Performance Under Two Stocking Rates on Fourwing Saltbush-Dominated Rangeland
}

\author{
Justin D. Derner ${ }^{1}$ and Richard H. Hart ${ }^{2}$ \\ Authors are ${ }^{1}$ Rangeland Scientist and ${ }^{2}$ Rangeland Scientist (retired), US Department of Agriculture-Agricultural Research Service \\ (USDA-ARS), High Plains Grasslands Research Station, 8408 Hildreth Road, Cheyenne, WY 82009.
}

\begin{abstract}
The efficiency of livestock production in shortgrass steppe may be increased by grazing fourwing saltbush (Atriplex canescens [Pursh] Nutt)-dominated rangeland in late fall and/or early spring, but there is a paucity of information concerning stocking rates and animal gains. The objective of this study was to compare the effects of light and moderate stocking rates on weight gains of heifers grazing twice-replicated 16-ha pastures in late fall (November to mid-January) from 1996 to 1998 , and in early spring (April to mid-May) from 1996 to 1999 . Stocking rates for late fall (light: $1.3-1.5$ ha $\cdot$ animal unit month $^{-1}$ [AUM ${ }^{-1}$ ] vs. moderate: $0.8-1.0 \mathrm{ha} \cdot \mathrm{AUM}^{-1}$ ) and early spring (light: $3.7-4.0 \mathrm{ha} \cdot \mathrm{AUM}^{-1}$ vs. moderate: $2.3-2.5 \mathrm{ha}^{\circ} \mathrm{AUM}^{-1}$ ) were achieved using 5 (for light grazing) and 8 (for moderate grazing) Hereford heifers, with initial average weights of $405 \pm 5.7$ (mean \pm 1 SE) $\mathrm{kg}$ for the late fall grazing period and $267 \pm 3.8 \mathrm{~kg}$ for the early spring grazing period across the study years. Average daily gain was $58 \%$ greater for light $\left(0.65 \pm 0.06 \mathrm{~kg} \cdot \mathrm{head}^{-1} \cdot \mathrm{d}^{-1}\right)$ compared to moderate $\left(0.41 \pm 0.05 \mathrm{~kg} \cdot \mathrm{head}-1 \cdot \mathrm{d}^{-1}\right) \mathrm{stocking}$ rates in the late fall grazing period, and $115 \%$ greater with light $\left(0.59 \pm 0.06 \mathrm{~kg} \cdot \mathrm{head}^{-1} \cdot \mathrm{d}^{-1}\right)$ than with moderate $\left(0.27 \pm 0.07 \mathrm{~kg} \cdot \mathrm{head}^{-1} \cdot \mathrm{d}^{-1}\right)$ stocking rates in the early spring grazing period. Beef production did not differ between stocking rates for either the late fall $\left(16.4 \pm 3.9\right.$ vs. $17.4 \pm 4.5 \mathrm{~kg}$ gain $\cdot \mathrm{ha}^{-1}$, light vs. moderate stocking rates) or early spring $\left(9.6 \pm 2.7\right.$ vs. $7.6 \pm 4.8 \mathrm{~kg}$ gain $\left.\cdot \mathrm{ha}^{-1}\right)$ grazing periods. We suggest that land managers employ light stocking rates during both grazing periods to obtain adequate individual animal gains without sacrificing gains per unit land area. Lengthening the grazing season in the shortgrass steppe should be economically desirable to land managers because feed costs could be lowered and animal gains obtained through minimal input.
\end{abstract}

\section{Resumen}

La eficiencia de la producción del ganado en los pastizales de zacates cortos puede ser incrementada con el apacentamiento de pastizales dominados por "Fourwing saltbush" (Atriplex canescens [Pursh] Nutt) a fines de otoño y/o inicios de primavera, pero hay una escasez de información concerniente a las cargas animal y ganancias del animal. El objetivo de este estudio fue comparar los efectos de cargas animal ligeras y moderadas en las ganancias de peso de vaquillas apacentando a fines de otoño (Noviembre a mediados de Enero) potreros de 16 ha repetidos dos veces, durante el periodo de 1996 a 1998 y a inicios de primavera (Abril a mediados de Mayo) de 1996 a 1999. Las cargas animal (ha $\mathrm{UAM}^{-1}$ ) para fines de otoño (ligero: $1.3-1.5$ vs. moderado: 0.8-1.0) e inicios de primavera (ligero: 3.7-4.0 vs. moderado: 2.3-2.5 ha UAM $^{-1}$ ) fueron logradas usando 5 (ligero) y 8 (moderado) vaquillas herford, con pesos iniciales promedio de $405 \pm 5.7 \mathrm{~kg}$ para el periodo de apacentamiento de fines de otoño y $267 \pm 3.8 \mathrm{~kg}$ para los periodos de apacentamiento a inicios de primavera a través de los años de estudio. La ganancia diaria promedio fue $58 \%$ mayor para la carga ligera $\left(0.65 \pm 0.06 \mathrm{~kg} \mathrm{hd}^{-1} \mathrm{~d}^{-1}\right.$, media $\left.\pm 1 \mathrm{EE}\right)$ en comparación con la carga moderada $\left(0.41 \pm 0.05 \mathrm{~kg} \mathrm{hd}^{-1} \mathrm{~d}^{-1}\right)$, esto para las cargas del periodo de fines de otoño y $115 \%$ mayor con la carga ligera $\left(0.59 \pm 0.06 \mathrm{~kg} \cdot \mathrm{hd}^{-1} \cdot \mathrm{d}^{-1}\right)$ que con la moderada $\left(0.27 \pm 0.07 \mathrm{~kg} \cdot \mathrm{hd}^{-1} \cdot \mathrm{d}^{-1}\right)$ en el periodo de inicios de primavera. La producción de carne no difirió entre cargas animal, tanto en los periodos de apacentamiento de fines de otoño, (16.4 \pm 3.9 vs. $17.4 \pm 4.5 \mathrm{~kg}$ ganacia $\mathrm{ha}^{-1}$, carga ligera vs. moderada) como los de inicios de primavera $(9.6 \pm 2.7 \mathrm{vs} .7 .6 \pm 4.8 \mathrm{~kg}$ gain $\left.\cdot \mathrm{ha}^{-1}\right)$. Sugerimos que los manejadores de pastizales empleen cargas ligeras en ambos periodos de apacentamiento para obtener ganancias animal individuales adecuadas sin sacrificar las ganancias por unidad de área. Alargar la estación de apacentamiento en los pastizales de zacates cortos debe ser económicamente deseable para los manejadores del pastizal conforme los costos de alimentación pudieran ser bajados y las ganancias animal sean obtenidas con entradas mínimas.

Key Words: Atriplex canescens, beef production, Central Great Plains, shortgrass steppe

\section{INTRODUCTION}

The USDA-ARS, Northern Plains Area, is an equal opportunity/affirmative action employer, and all agency services are available without discrimination.

Correspondence: Justin Derner, USDA-ARS High Plains Grasslands Research Station, 8408 Hildreth Road, Cheyenne, WY 82009. Email: Justin.Derner@ars.usda.gov

Manuscript received 17 December 2004; manuscript accepted 10 May 2005.
Livestock producers in the shortgrass steppe ecosystem have traditionally grazed their cattle on native rangeland from midMay to late October. Unlike the more mesic environments in the Great Plains region where grazing of crop residues can provide complementary forage following the summer grazing season, the wheat-fallow cropping regime prominently used in this semiarid environment does not provide such an opportunity. 
Table 1. Descriptive parameters for late fall and early spring grazing periods under light $(\mathrm{L})$ and moderate (M) stocking rates on fourwing saltbush (Atriplex canescens)-dominated rangeland.

\begin{tabular}{|c|c|c|c|c|c|c|c|c|c|c|c|c|c|c|}
\hline \multirow[b]{3}{*}{ Parameter } & \multicolumn{6}{|c|}{ Late Fall } & \multicolumn{8}{|c|}{ Early Spring } \\
\hline & \multicolumn{2}{|c|}{1996} & \multicolumn{2}{|c|}{1997} & \multicolumn{2}{|c|}{1998} & \multicolumn{2}{|c|}{1996} & \multicolumn{2}{|c|}{1997} & \multicolumn{2}{|c|}{1998} & \multicolumn{2}{|c|}{1999} \\
\hline & L & $M$ & $\mathrm{~L}$ & M & $\mathrm{L}$ & M & L & $\mathrm{M}$ & L & $M$ & L & $\mathrm{M}$ & L & $\mathrm{M}$ \\
\hline Grazing period (days) & \multicolumn{2}{|c|}{70} & \multicolumn{2}{|c|}{84} & \multicolumn{2}{|c|}{82} & \multicolumn{2}{|c|}{45} & \multicolumn{2}{|c|}{43} & \multicolumn{2}{|c|}{41} & \multicolumn{2}{|c|}{49} \\
\hline Head (no.) & 5 & 8 & 5 & 8 & 5 & 8 & 5 & 8 & 5 & 8 & 5 & 8 & 5 & 8 \\
\hline Entry weight (kg) & 405 & 408 & 409 & 398 & 402 & 408 & 256 & 244 & 276 & 287 & 295 & 287 & 247 & 245 \\
\hline AUE & \multicolumn{2}{|c|}{0.9} & \multicolumn{2}{|c|}{0.9} & \multicolumn{2}{|c|}{0.9} & \multicolumn{2}{|c|}{0.55} & \multicolumn{2}{|c|}{0.6} & \multicolumn{2}{|c|}{0.6} & \multicolumn{2}{|c|}{0.55} \\
\hline Stocking rate $\left(\text { ha } \cdot \mathrm{AUM}^{-1}\right)^{1}$ & 1.5 & 1.0 & 1.3 & 0.8 & 1.3 & 0.8 & 4.0 & 2.5 & 3.7 & 2.3 & 4.0 & 2.5 & 3.7 & 2.3 \\
\hline Stocking density $\left(\mathrm{AUD} \cdot \mathrm{ha}^{-1}\right)$ & 19.7 & 31.5 & 23.6 & 37.8 & 23.1 & 36.9 & 7.7 & 12.4 & 8.1 & 12.9 & 7.7 & 12.3 & 8.4 & 13.5 \\
\hline
\end{tabular}

${ }^{1} \mathrm{AVE}$ indicates animal unit equivalent; $\mathrm{AUM}^{-1}$, animal units per month; $\mathrm{AUD}$, animal unit day.

Therefore, most producers provide supplemental hay, energy, and protein feedstuffs to livestock from November until the next summer's grazing season. The efficiency of livestock production in shortgrass steppe may be increased by grazing fourwing saltbush (Atriplex canescens [Pursh] Nutt)-dominated rangeland in late fall and/or early spring. This saltbush-dominated rangeland would be deferred during the traditional summer grazing season to extend the grazing season and provide opportunities for additional animal gain via grazing. A problem with the use of saltbush-dominated rangeland in late fall and early spring in the shortgrass steppe is the paucity of information concerning stocking rates and animal gains.

Fourwing saltbush is adapted to semiarid conditions and produces palatable, digestible, high-protein forage (Rumbaugh et al. 1982; Otsyina et al. 1984; Cordova and Wallace 1985; Otsyina and McKell 1986; Garza and Fulbright 1988; Ueckert et al. 1990). Fourwing saltbush plants typically begin rapid growth in May, flower during June, and complete seed set by the end of August. Trlica et al. (1977) determined that the most detrimental period for defoliating fourwing saltbush is near maturity (i.e., flower production) compared to defoliations at quiescence or during early or rapid growth. Furthermore, Buwai and Trlica (1977) demonstrated that moderate defoliations (i.e., $60 \%$ removal of current year's growth) at rapid growth, seed set, and quiescence stimulated twig growth, but heavy defoliations (i.e., $90 \%$ removal) could kill plants. These authors did suggest, however, that use of fourwing saltbush in either early spring or late fall may not affect plants.

Utilization of fourwing saltbush leaders by cattle is temporally variable because the percentage of leaders grazed was 2fold greater in January compared to April in a shortgrass steppe (Cibils et al. 2003a). It is currently unclear, however, if these temporal differences in utilization of fourwing saltbush leaders are translated to differences in animal performance when grazed in late fall or early spring. The objective of this study was to compare the effects of light and moderate stocking rates on weight gains of yearling heifers grazing rangeland dominated by fourwing saltbush during the late fall (November to midJanuary) and early spring (April to mid-May) from 1996 to 1999. There is generally a negative response of productivity per animal with increases in stocking rate, but an increase in productivity per unit area with increasing stocking rate until scarcity of forage negatively influences animal intake (Bement 1969; Holechek et al. 1998). Therefore, we hypothesized that, for both grazing periods, light stocking rates would result in greater individual animal weight gains, but that moderate stocking rates would result in greater gains per unit land area.

\section{MATERIALS AND METHODS}

Our study site was on the US Department of AgricultureAgricultural Research Station Central Plains Experimental Range, approximately $60 \mathrm{~km}$ northeast of Fort Collins, Colorado (lat $40^{\circ} 49^{\prime} \mathrm{N}$, long $107^{\circ} 47^{\prime} \mathrm{W}$ ). We conducted our research on a floodplain area with Remmit (coarse-loamy, mixed, superactive mesic Ustic Haplocambids) and Edgar (fineloamy, mixed, superactive, mesic Haplocalcidic Haplustepts) soil series. Fourwing saltbush, blue grama (Boutelona gracilis [H.B.K.] Lag. ex Griffiths), and western wheatgrass (Pascopyrum smithii [Rydb.] A. Love) are the dominant plant species at the site (Liang et al. 1989). Mean annual precipitation is 321 $\mathrm{mm}$, and mean annual temperature is $8.6^{\circ} \mathrm{C}$ (Lauenroth and Sala 1992). Precipitation was above average in all 4 years of this study: 1996 (387 mm), 1997 (565 mm), 1998 (422 mm), and 1999 (557 $\mathrm{mm})$.

Hereford heifers grazed twice-replicated 16-ha experimental pastures during each grazing period: early spring (April to midMay, 45 days) for 4 years (1996-1999) and late fall (November to mid-January, 79 days) for 3 years (1996-1998) (Table 1). The shorter duration of grazing for the early spring grazing period is attributable to the transfer of animals from saltbushdominated pastures to shortgrass steppe pastures for summer grazing in mid-May. Grazing did not begin earlier than April 1 for the early spring period to reduce risks associated with extreme weather events (i.e., blizzards). The experimental pastures were fenced in summer 1996 and had a prior history of winter-season use at moderate stocking rates. Aerial photography in 1996 indicated that the density of fourwing saltbush across the experimental pastures was 1646 plants $\mathrm{ha}^{-1}$ (D. T. Booth, personal communication, October 2004). Fourwing saltbush plants in pastures adjacent to the study area with the same grazing history had a maximum crown diameter of $81 \mathrm{~cm}$ and an average height of $66 \mathrm{~cm}$ (Cibils et al. 2000).

Light (1.3-1.5 ha-animal unit month $\left.{ }^{-1}\left[\mathrm{AUM}^{-1}\right]\right)$ and moderate $\left(0.8-1.0 \mathrm{ha} \cdot \mathrm{AUM}^{-1}\right)$ stocking rates for the late fall grazing period were achieved using 5 (for light grazing) and 8 (for moderate grazing) randomly allocated Hereford long 
yearling heifers with initial average weights of $405 \pm 5.7$ (mean $\pm 1 \mathrm{SE}$ ) $\mathrm{kg}$ across the study years (Table 1). These stocking rates resulted in stocking densities of 19.7-23.6 animal unit days (AUD) $\cdot \mathrm{ha}^{-1}$ for the light stocking rate and 31.5-37.8 AUD $\cdot \mathrm{ha}^{-1}$ for the moderate stocking rate. For the early spring grazing period, 5 and 8 randomly allocated Hereford yearling heifers, with initial average weights of $267 \pm 3.8 \mathrm{~kg}$ across the study years were used to achieve light $\left(3.7-4.0 \mathrm{ha} \cdot \mathrm{AUM}^{-1}\right)$ and moderate $\left(2.3-2.5 \mathrm{ha} \cdot \mathrm{AUM}^{-1}\right)$ stocking rates, respectively (Table 1 ). Lower average entry weights of the Hereford heifers for the early spring grazing period is due to the younger age of these animals (approximately 12 months) compared to those grazing in late fall (approximately 18 months). The light stocking rate achieved a stocking density of $7.7-8.4$ AUD $\cdot \mathrm{ha}^{-1}$ and the moderate stocking rate a stocking density of 12.3-13.5 AUD $\cdot \mathrm{ha}^{-1}$. Although body condition scores for the Hereford heifers were not taken, all heifers were healthy in appearance and had received good nutrition prior to being placed on study pastures (M. M. Ashby, personal communication, October 2004). The stocking rate initially randomly assigned to each experimental pasture was used for the duration of this study. Pastures without fourwing saltbush were not included as controls in this study because of the difficulty in finding comparable pastures on floodplain areas with the same soil series that did not have fourwing saltbush.

Animals were fed prairie hay ad libitum only when snow covered the herbaceous vegetation. No protein supplement was fed during either grazing period. Animal gains of the heifers were determined by weighing individual animals at the beginning and end of each grazing season period. Beef production per ha $\left(\mathrm{kg} g a i n \cdot \mathrm{ha}^{-1}\right)$ was determined by summing individual animal gains by treatment and replication for each grazing season period and dividing by the number of ha in the pasture.

Data were analyzed separately for each grazing period (late fall and early spring) because of different initial cattle weights and length of grazing periods. We used a 2-factor analysis of variance (ANOVA) with year and stocking rate (light or moderate) as the main factors. Means were separated by Duncan's multiple range test at the 0.05 level of probability.

\section{RESULTS}

Average daily gain (ADG, $\mathrm{kg} \cdot \mathrm{head} \cdot{ }^{-1} \cdot \mathrm{d}^{-1}$ ) of Hereford yearling heifers was $58 \%$ greater for light $(F=16.64, \mathrm{df}=1$, $P=0.0003)$ compared to moderate stocking rates in the late fall grazing period, and $115 \%$ greater with light $(F=49.72$, $\mathrm{df}=1, P<0.0001)$ than with moderate stocking rates in the early spring grazing period over the duration of this study (Fig. 1). Observed ADG tended to be higher for the late fall than for the early spring grazing period, especially for the moderate stocking rate. Stocking rate did not interact with year to affect ADG. Year did affect ADG; 1997 data differed from the other years for both the late fall $(F=14.52, \mathrm{df}=2, P<0.0001)$ and early spring $(F=61.68, \mathrm{df}=3, P<0.0001)$ grazing periods. For example, in 1997 ADG was approximately 2-fold greater across stocking rates for the late fall grazing period compared to the other years, which did not differ from one
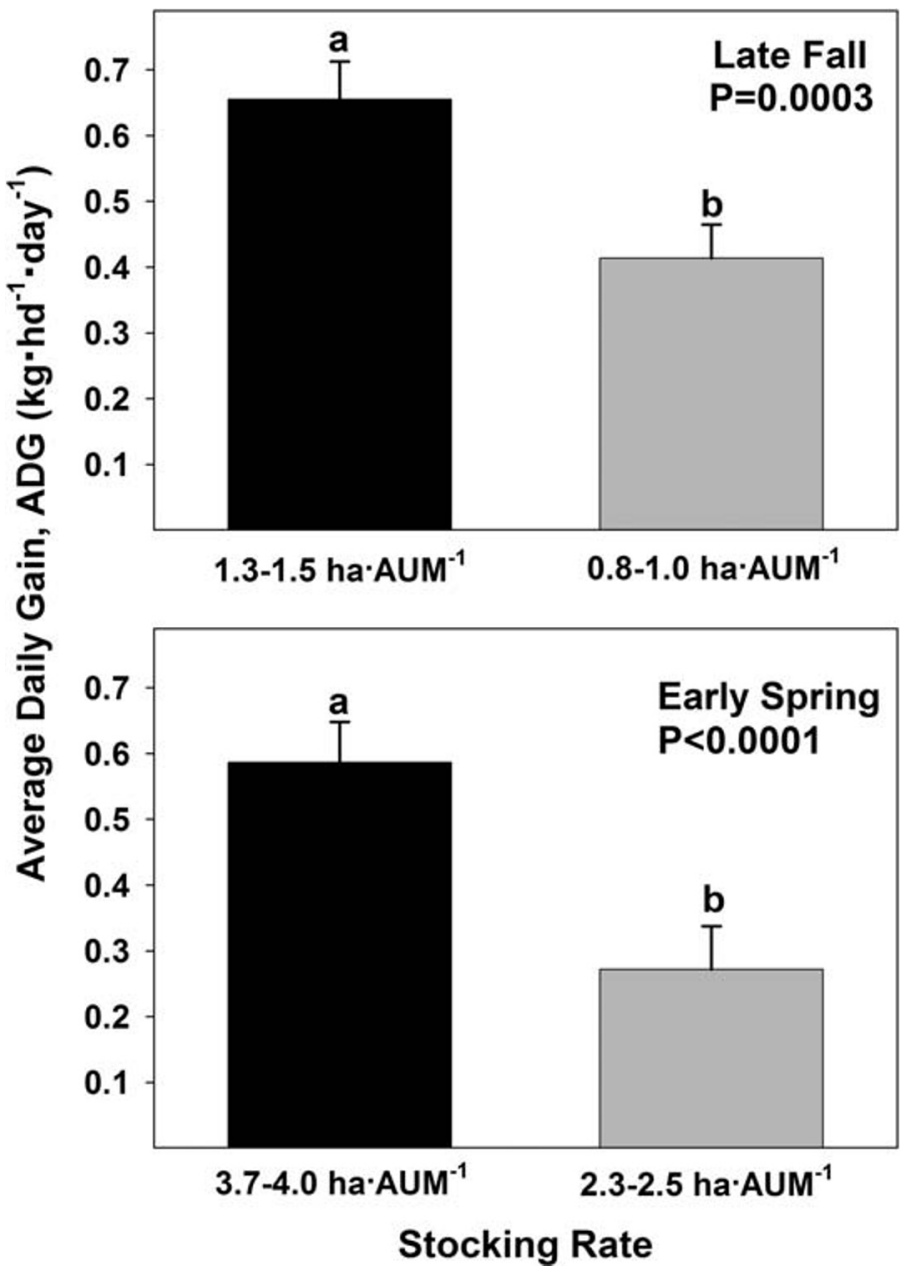

Figure 1. Average daily gain $\left(\mathrm{kg} \cdot \mathrm{head}^{-1} \cdot \mathrm{d}^{-1}\right)$ of yearling Hereford heifers in response to light and moderate stocking rates on 16-ha fourwing saltbush (Atriplex canescens)-dominated rangeland in late fall (November to mid-January, upper panel) and early spring (April to midMay, lower panel) grazing periods from 1996 to 1999. Error bars are the standard error of the mean.

another (Fig. 2). Similarly, ADG across stocking rates in 1997 for the early spring grazing period was negative, whereas the other 3 years were comparable at 0.54 to 0.58 $\mathrm{kg} \cdot \mathrm{head}^{-1} \cdot \mathrm{day}^{-1}$. Beef production, expressed as $\mathrm{kg}$ gain $\cdot \mathrm{ha}^{-1}$, did not differ between stocking rates for either the late fall $(16.4 \pm 3.9$ [mean $\pm 1 \mathrm{SE}]$ vs. $17.4 \pm 4.5 \mathrm{~kg}$ gain $\cdot \mathrm{ha}^{-1}$, light vs. moderate stocking rates, $F=0.03, \mathrm{df}=1, P=0.8708$ ) or early spring $\left(9.6 \pm 2.7\right.$ vs. $7.6 \pm 4.8 \mathrm{~kg}$ gain $\cdot \mathrm{ha}^{-1}, F=0.14$, $\mathrm{df}=1, P=0.7254)$ grazing period.

\section{DISCUSSION}

Individual gains of yearling Hereford heifers on fourwing saltbush-dominated rangeland were influenced by stocking rate for both the late fall (November to mid-January) and early spring (April to mid-May) grazing periods, but beef production was similar for both stocking rates in each of the grazing periods. 


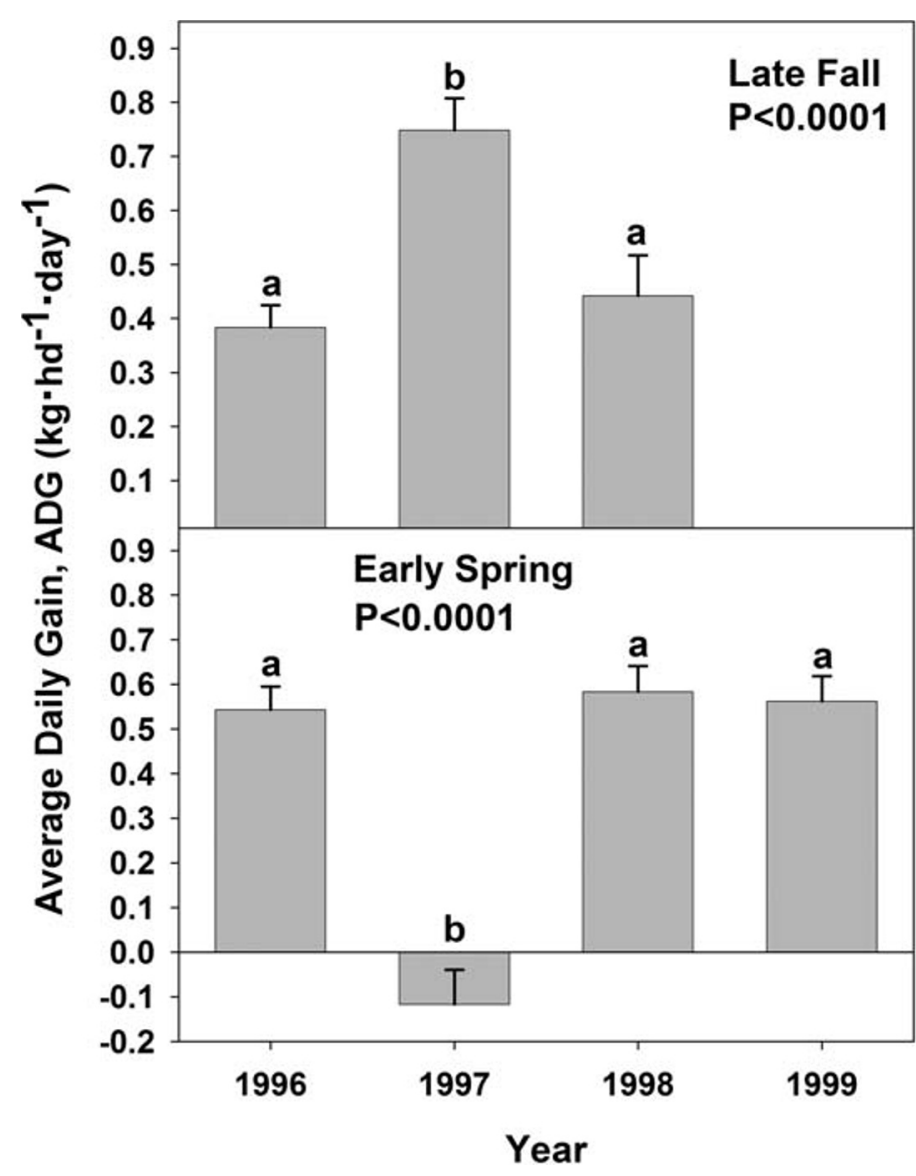

Figure 2. Average daily gain $\left(\mathrm{kg} \cdot \mathrm{head}^{-1} \cdot \mathrm{d}^{-1}\right)$ of yearling Hereford heifers by year for late fall (November to mid-January, upper panel) and early spring (April to mid-May, lower panel) grazing periods across light and moderate stocking rates on 16-ha fourwing saltbush (Atriplex canescens)-dominated rangeland. Error bars are the standard error of the mean.

We observed greater individual animal weight gains with light compared to moderate stocking rates for both of the grazing periods, supporting our hypothesis. The finding of similar beef production, or gain per ha, between the 2 stocking rates for each of the grazing periods did not support our hypothesis that moderate stocking rates would result in greater gains per unit land area. Collectively, these findings suggest that land managers in the shortgrass steppe can effectively extend their grazing season by utilizing fourwing saltbush-dominated rangeland both prior to and following the traditional summer grazing season using light stocking rates which enhance individual animal gains without sacrificing gains per unit land area.

Our finding that individual animals gained weight while grazing fourwing saltbush-dominated rangeland, both in the late fall and early spring, is consistent with the speculation of Boutouba et al. (1990) in which inclusion of fourwing saltbush in diets with low-quality grasses will be most beneficial during the dormant season. Additionally, Ueckert et al. (1990) demonstrated that ewes grazing a fourwing saltbush-bluestem mixture maintained weight whereas ewes grazing 'WW-Spar' bluestem (Bothriochloa ischaemum L.) monocultures lost $4.2 \mathrm{~kg} \cdot \mathrm{head}^{-1}$ during 2 winter months. The maintenance or gain of weight by animals grazing fourwing saltbush-dominated rangeland is likely attributable to the preference of fourwing saltbush plants by grazing animals, especially during periods when green herbaceous vegetation is absent (Cibils 1999), because fourwing saltbush was found in greater proportion in cattle diets than that on offer at both high $(19 \%)$ and low $(8 \%)$ levels of saltbush frequency (Shoop et al. 1985). Although fourwing saltbush has a high protein concentration (12-28\%) (Rumbaugh et al. 1982; Garza and Fulbright 1988, Cibils 1999), and goats fed a diet containing $60 \%$ fourwing saltbush leaves retained more nitrogen than those fed a $30 \%$ ration (Boutouba et al. 1990), the increased utilization of fourwing saltbush may not fully account for the greater beef production, because the nutritional value of this plant is considerably overestimated by standard laboratory techniques (Ueckert et al. 1990). These authors speculated that fourwing saltbush forage contains plant secondary metabolites that may interfere with nitrogen retention (Robbins et al. 1987; Sanderson et al. 1987).

ADG trended higher for the late fall than for the early spring grazing period, especially for the moderate stocking rate. This is consistent with patterns of greater (2-fold) utilization of leaders on fourwing saltbush (Cibils et al. 2003a), as well as fourwing saltbush having a greater contribution to cattle diets (Cibils 1999) in late fall compared to the early spring grazing period. Differences in ADG between grazing periods may be attributable to heifers in the late fall grazing period having greater rumen maturity to efficiently utilize forage on offer because they were older ( 18 vs. 12 months) than heifers in the early spring grazing period. In addition, reduced gains in the early spring grazing period may be due to lower animal preference for fourwing saltbush plants, despite similar percent nitrogen in fourwing saltbush tissues across grazing periods (Cibils 1999), because most female shrubs shed almost all their utricles prior to early spring (Cibils 1999). Greater gains in the late fall than in the early spring grazing period occurred despite new growth of $\mathrm{C}_{3}$ grasses (e.g., western wheatgrass) and higher selectivity for grasses than for fourwing saltbush (Cibils 1999) in the spring, suggesting that the growth of this plant functional group was insufficient to produce animal gains or that the gains produced following initiation of growth in the spring did not compensate for poor animal performance when the heifers were consuming older accumulated herbaceous standing crop with lower dietary quality $(6.2-7.2 \%$ crude protein, Shoop et al. 1978). The importance of weather influences may also impact animal performance more in the early spring grazing period as was illustrated by the heavy snowfall during the winter of 1997 . This snowfall likely reduced availability of the herbaceous understory for the heifers and, as such, can be implicated in contributing to the decreased animal performance in the early spring 1997 grazing period.

Annual precipitation during all years of this study was slightly to well-above average. The much-above-average precipitation received in $1997(565 \mathrm{~mm})$ resulted in 34\% greater forage production than long-term (1991-2004) values on adjacent upland shortgrass steppe pastures (1 033 vs. $769 \mathrm{~kg} \cdot \mathrm{ha}^{-1}$, J. D. Derner, unpublished data), suggesting greater-than-normal grass production would also be expected in the saltbushdominated pastures. This expected greater production would have provided an abundant grass residue base for the heifers during the late fall grazing period in that year. Since understory 
herbaceous vegetation has a higher crude protein concentration when grown in proximity to fourwing saltbush (Rumbaugh et al. 1982), this implies that not only was there more grass biomass on offer because of the wet conditions, but that this forage was of higher quality than that on offer in pastures without fourwing saltbush. The nutritional status of goats on a low-quality grass diet, similar to what would be on offer to the yearling heifers in this study, was enhanced on a diet containing 30\% fourwing saltbush (Nunez-Hernandez et al. 1989). Whether the results we obtained would differ in below-average precipitation years in which grass production in these pastures may be limiting is unknown, but we speculate that both individual animal gain and gain per unit land area would both decrease. Land managers would likely respond to dry conditions by reducing stocking rates or by increasing supplemental feeding of hay or other feedstuffs under these circumstances.

Similar beef production per unit land area when using both light and moderate stocking rates, both for late fall and early spring grazing periods, demonstrates that the increased stocking rate did not compensate for the lower individual animal gain achieved with the moderate stocking rate. Therefore, there is not an economic advantage to increasing stocking rates from light to moderate levels when grazing saltbush in the shortgrass steppe. The finding of adequate livestock gains with light stocking rates in both the late fall and early spring grazing periods, combined with previous findings that fourwing saltbush plants clipped in either fall or spring exhibited equal recovery following clipping (Rumbaugh et al. 1982), suggests that incorporating light stocking rates not only provides reasonable beef production, but also is a sustainable land management practice that should not degrade the rangeland resource. The use of fourwing saltbush-dominated rangeland in either late fall or early spring is further supported by previous findings suggesting that periodic rest is needed to maintain fourwing saltbush populations (Pieper and Donart 1978), because continuous grazing results in marginal plant regrowth (Price et al. 1989), reduced population densities (Schuman et al. 1990), and increased composition of nonflowering plants (Cibils et al. 2003b).

\section{MANAGEMENT IMPLICATIONS}

Land managers in the shortgrass steppe can lengthen their grazing seasons by using rangeland dominated by fourwing saltbush in early spring and late fall, prior to and following the traditional summer grazing period. We suggest that land managers employ light stocking rates in both the early spring and late fall grazing periods to obtain adequate individual animal gains. Producers could expect animal performance in above-normal precipitation years to be approximately 0.6 $\mathrm{kg} \cdot$ head $^{-1} \cdot$ day $^{-1}$ with the light stocking rate, but only about half this level if stocking rates are increased to moderate levels. Climatic events such as excessive snowfall and years with below-average precipitation will most likely dampen animal performance. Lengthening of the grazing season in the shortgrass steppe should be economically desirable to land managers because feed costs could be lowered and animal gains obtained through minimal input.

\section{ACKNOWLEDGMENTS}

Mary Ashby and Jeff Thomas collected animal data at the Central Plains Experimental Range. Crow Valley Livestock Cooperative, Inc. provided the heifers.

\section{LITERATURE CITED}

BEMENT, R. E. 1969. A stocking rate guide for beef production on blue grama range. Journal of Range Management 22:83-86.

Boutouba, A., J. L. Holechek, M. L. Galyean, G. Nunez-Hernandez, J. D. Wallace, and M. CaRdenas. 1990. Influence of two native shrubs on goat nitrogen status. Journal of Range Management 43:530-534.

Buwal, M., AND M. J. TRLICA. 1977. Multiple defoliation effects on herbage yield, vigor, and total nonstructural carbohydrates of five range species. Journal of Range Management 30:164-171.

CIBILS, A. F. 1999. Cattle-shrub interactions in an Atriplex canescens dominated community of the shortgrass steppe [dissertation]. Fort Collins, CO: Colorado State University. 130p. Available from: Colorado Sate University, Fort Collins, CO.

Cibils, A. F., D. M. Swift, and R. H. HaRt. 2000. Gender-related differences of shrubs in stands of Atriplex canescens with different histories of grazing by cattle. Journal of Arid Environments 46:383-396.

Cibils, A. F., D. M. Swift, and R. H. HaRt. 2003a. Female-biased herbivory in fourwing saltbush browsed by cattle. Journal of Range Management 56: $47-51$.

Cibils, A. F., D. M. Swift, and R. H. HaRt. 2003b. Changes in shrub fecundity in fourwing saltbush browsed by cattle. Journal of Range Management 56: $39-46$.

Cordova, F. J., and J. Wallace. 1985. Nutritive value of some browse and forb species. Proceedings Western Section of American Society of Animal Science 26:160-162.

Garza, A., JR., and T. E. Fulbright. 1988. Comparative chemical composition of armed saltbush and fourwing saltbush. Journal of Range Management 41:401-403.

Holechek, J. L., R. D. Pieper, and C. H. Herbel. 1998. Range managementPrinciples and practices, 3rd ed. Upper Saddle River, NJ: Prentice Hall. 542 p.

LauenRoth, W. K., and O. E. Sala. 1992. Long-term forage production of North American shortgrass steppe. Ecological Applications 2:397-403.

Liang, Y. M., D. L. Hazlett, and W. K. Lauenroth. 1989. Biomass dynamics and water use efficiencies of five plant communities in the shortgrass steppe. Oecologia 80:148-153.

Nunez-Hernandez, G., J. L. Holechek, J. D. Wallace, M. L. Galyean, A. Tembo, R. Valdez, and M. CaRdenas. 1989. Influence of native shrubs on nutritional status of goats: nitrogen retention. Journal of Range Management 42:228-232.

Otsyina, R., And C. M. McKell. 1986. Fodder shrubs as dietary supplements to mature grasses for fall grazing of sheep. In: P. W. Lynch, P. J. Joss, and 0 . B. Williams [EDS.]. Rangelands: A resource under siege. Proceedings, 2nd International Rangeland Congress; 13-18 May 1984. Canberra, Australia: Australian Academy of Science. p. 320-321.

Otsyina, R. M., C. M. McKell, J. M. Malecheck, and G. A. Van Epps. 1984. Potential of Atriplex and other chenopod shrubs for increasing range productivity and fall and winter grazing use. In: A. R. Tiedemann, E. D. McArthur, H. C. Stutz, R. Stevens and K. L. Johnson [ComPS.]. Proceedings, Symposium on Biology of Atriplex and Related Chenopods; 2-6 May 1983. Ogden, UT: US Forest Service General Technical Report INT-172. p. 215-219.

Pieper, R. D., and G. B. Donart. 1978. Response of fourwing saltbush to periods of protection. Journal of Range Management 31:314-315.

Price, D. L., G. B. Donart, and G. M. Southward. 1989. Growth dynamics of fourwing saltbush as affected by different grazing management systems. Journal of Range Management 42:158-162.

Robbins, C. T., T. A. Hanley, A. E. Hagerman, 0. Hueljord, D. L. Baker, C. C. Schwartz, And W. W. Mautz. 1987. Role of tannins in defending plants against ruminants: reduction in protein availability. Ecology 68:98-107. 
Rumbaugh, M. D., D. A. Johnson, and G. A. Van Epps. 1982. Forage yield and quality in a Great Basin shrub, grass, and legume pasture experiment. Journal of Range Management 35:604-609.

Sanderson, S. C., R. L. Pendleton, E. D. McArthur, and K. T. Harper. 1987. Saponin effect on small mammal forage preference in a planting of Atriplex canescens. In: F. D. Provenza, J. T. Flinders, and E. D. McArthur [comps.]. Proceedings, Symposium on Plant-herbivore interactions; 7-9 August 1985. Snowbird, UT: US Forest Service General Technical Report INT-222. p. 74-77.

Schuman, G. E., D. T. Booth, and J. W. Waggoner. 1990. Grazing reclaimed mined land seeded to native grasses in Wyoming. Journal of Soil and Water Conservation 45:653-657.

Shoop, M., G. P. Ruppp, E. E. Remmenga, P. J. Chenoweth, and L. Ball. 1978. Protein sources for cattle wintered on blue grama range. In: D. N. Hyder [ED.]. Proceedings, 1st International Rangeland Congress. 14-18 Au- gust 1978; Denver, CO.Lakewood, C0: Society for Range Mangement. p. 423-426.

Shoop, M. C., R. C. Clark, W. A. Laycock, and R. M. Hansen. 1985. Cattle diets on shortgrass ranges with different amounts of fourwing saltbush. Journal of Range Management 38:443-449.

Trlica, M. J., M. BuwAi, AND J. MenKE. 1977. Effects of rest following defoliations on the recovery of several range species. Journal of Range Management 30: 21-27.

Ueckert, D. N., J. L. Peterson, J. E. Huston, and M. W. Wagner. 1990. Evaluation of fourwing saltbush as a forage for sheep and Angora goats. In:E. D. McArthur, E. M. Romney, S. D. Smith, and P. T. Tueller [comps.]. Proceedings, Symposium on Cheatgrass Invasion, Shrub Die-off, and Other Aspects of Shrub Biology and Management; 5-7 April 1989. Las Vegas, NV: US Forest Service General Technical Report INT-276. p. 300-304. 